\title{
The Israel-Lebanon War of 2006 and the Failure of US Foreign Policy
}

\author{
Hamed Mousavi ${ }^{1}$ \\ ${ }^{1}$ Carleton University, Ottawa, Canada \\ Correspondence: Hamed Mousavi, Room B640, Loeb Building, Carleton University, 1125 Colonel by Drive, \\ Ottawa, ON, K1S 5B6, Canada. E-mail: hamed_mousavi@carleton.ca
}

Received: January 19, 2015 Accepted: February 5, 2015 Online Published: February 27, 2015

doi:10.5539/jpl.v8n1p130

URL: http://dx.doi.org/10.5539/jpl.v8n1p130

\begin{abstract}
This paper argues that the US encouraged the starting, continuation and even expansion of the 2006 Israeli war on Lebanon in order to achieve its own hegemonic objectives in the region. While global hegemony has always been on Washington's agenda, in the Bush administration, with neoconservatives sitting behind influential desks in the capital, the initiative got new impetus. According to this new approach, the goal was to be advanced with the confrontation and eventual defeat of the Iran-Syria-Hezbollah-Hamas axis, a move that would help create a 'New Middle East' in which opposition to US-Israeli policies would not be tolerated. The paper uses a Neoclassical Realist theoretical approach to show that Washington's miscalculation of power relations in the region led to the failure of its foreign policy. Like the Iraq War of 2003, the 2006 Lebanon War was a disaster for the US. With the encouragement and support of the Americans, the Israeli war machine fought an inconclusive war with Hezbollah, as a result of which the status of the Israeli military as the Middle East's 'Invincible Army' was shattered and archenemies Hezbollah and Iran were strengthened.
\end{abstract}

Keywords: 2006 Lebanon War, US foreign policy, neoclassical realism, Middle East politics, Israeli-Arab conflict, US-Israel relations

\section{Introduction}

On July $12^{\text {th }} 2006$ Hezbollah forces in a cross border attack on two Israeli armored Humvees killed three soldiers and took two soldiers prisoner. In retaliation Israel started a massive assault on Lebanon. What ensued was an open war between Israel and Hezbollah that lasted for 33 days, left over 1100 Lebanese and 43 Israelis killed and caused major destruction to Lebanese infrastructure with minimum estimates standing at 3.6 billion dollars. There are however estimates as high as 15 billion dollars on the destruction on Lebanese economy according to the UN development program (Zafiris \& Sayed, 2008). Israel's aim was to cause massive destruction to Lebanon, or to put it in the words of Israel's Chief of Staff, Dan Halutz, "turn Lebanon's clock back 20 years" (Avnery, 2007). The aim of this policy was to turn the Lebanese population against Hezbollah.

Initially there was wide spread speculation of pre-planning by Israel for the summer 2006 war, with the San Francisco Chronicle stating that Army officers had started giving power point presentations on a "three week assault" on Lebanon, with very similar details to the conflict in question, to the US administration and think thanks, almost a year in advance of July 2006 (Kalman, 2006). Speculation turned into fact when in a leaked testimony to the Winograd commission, Israeli Prime Minister Ehud Olmert confessed to have started planning for the conflict at least 4 months in advance. According to the leading Israeli newspaper Ha'aretz, which obtained the leaked testimony, Olmert discussed the possibility of war in January 2006 and asked to see military plans in March of the same year (Urquhart, 2007).

In the years prior to the 2006 conflict some elements of the Bush administration especially in the State department had advised restraint on Israeli assaults on the occupied Palestinian territories mainly due to the fact that the US was fighting a war in Iraq and was working to "win the hearts and minds" of the Iraqis. The state department and more sensible elements within the administration were strongly against any joint Israeli-US military efforts mainly due to the fact that the State Department correctly believed that this would make the 'War on Terror' look like a US-Israeli war on Muslim countries. However when the time came America's actual policy was much more in tune with the views of hawkish neoconservatives who were occupying key positions in Washington. This article will try to address how and why the US administration encouraged the starting, continuation and even expansion of the 2006 Israeli war on Lebanon using a neoclassical realist theoretical 
framework.

\section{Theoretical Framework}

In the Theory of International Politics, Kenneth Waltz (1979) lays the foundation of Neorealist IR theory by isolating structural variables and ignoring state level variables. The theory's main assumption is that unlike domestic politics, the state of international affairs is one of anarchy. His theory also takes states as the main actors of this arena and assumes that they rely on self-help to ensure their survival. All these are core realist assumptions and are shared by scholars such as Carr, Morgenthau, Mearsheimer and even classical writers such as Machiavelli, Hobbes and Thucydides. However what makes Waltz's theory unique is that by distinguishing between structure and process he is able to build a theory that is both parsimonious and powerful. His theory is based on the assumption that the position of units in the system is not a property of the units themselves but rather a property of the system and thus by studying the system one can find regularities in state behavior. Another logical conclusion to this assumption is that the structure only changes when the arrangement of its parts changes and not by any change in process level variables. Thus by isolating the third image from the first and second images, Waltz aims to explain the constraints imposed on the units by the structure. Therefore the third image is influencing and affecting the first two images, not the other way round. A well-devised structural theory will explain how states with vastly different unit level variables will behave similarly due to the impositions of the structure (Waltz, 1979, pp. 79-101). Nevertheless while neorealism provides important improvements over past realist approaches, it has been criticized for completely ignoring domestic level factors such as the ideological orientations of decision makers. This weakness of Waltz's theory is caused by its assumption that all states are homogeneous units of the international system (Rosecrance, 1981, pp. 700-708). To address these weaknesses neoclassical realism brings unit level factors into the analysis, while at the same time accepting many of neorealism's assumptions.

Neoclassical realists assert that a state's foreign policy is driven primarily by its place in the international system and its relative material capabilities. This is a major area of commonality with neorealist theory. Where it differs from structural theory is that it argues that a state's relative power in the system is not directly translated into foreign policy. Rather its impact is dependent on unit level "intervening variables" which act in between the independent (relative power capabilities) and dependent (foreign policy) variables. Neoclassical realists for example stress that the perception of decision makers and domestic state structures are key to how states view the international system and how they define their country's interests. By accounting for intervening variables that 'translate' the independent variable, realist theory becomes more complex but at the same time results in greater accuracy and specificity (Rose, 1998, pp. 166-167). Neoclassical Realism also differs from constructivism in that the main driver of a state's foreign policy is its relative power capabilities and the other factors pointed earlier only act as intervening variables, whereas constructivism sees norms as constituting the very identity and interests of states. Also there are objective structural constraints and incentives on state behavior in neoclassical realism and as a result anarchy is not what states make of it. As future sections will demonstrate neoclassical realism can be successfully used to analyze how the ideology of decision makers can affect American policy in the Middle East in negative ways.

\section{Encouragement Beyond the Usual Endorsement}

From the start of the 2006 Lebanon War it was evident that the Bush administration strongly supported Israel's war with its northern neighbor. This support came through in terms of both public statements and more importantly via actions on the ground. A day after the war started President Bush repeated the right of Israel to "defend" itself, which is usually used by Washington whenever Israel attacks its opponents with disproportional force. The American President also called Hezbollah "the root of the problem" (CTV News, 2006). The US Congress tried not to fall behind the executive branch in supporting Israel by passing Senate resolution 534 with a 98-0 vote, "Condemning Hezbollah and Hamas and their state sponsors and supporting Israel's exercise of its right to self-defense" (United Sates Senate, 2006, p. Res.534), and the house passing resolution 921 with a 410-8 vote, with such an exaggerated tone that is hard to find even in Israel. On the ground according to the New York Times, Washington expedited the delivery of satellite and laser guided bombs to Israel (Reuters, US rushes precision-guided bombs to Israel: paper, 2006). Also on July $14^{\text {th }}$ just two days after the start of the conflict the US Congress was notified of a very large JP-8 jet fuel shipment to Israel amounting to 210 million dollars so that "the jet fuel will be consumed while the aircraft is in use to keep peace and security in the region" (Defense Security Cooperation Agency, 2006), or to put it in other terms it was needed for the Israeli Air Force more than 12,000 combat missions in the 33 war. It was reported on July $24^{\text {th }}$ that the US was going to provide 'Bunker Buster' bombs to Israel, which were allegedly used to target Hezbollah's leadership (Reuters, Israel to get U.S. "bunker buster" bombs, 2006). 
All of this however should come at no surprise since Israel has long been Washington's "special" ally in the region, enjoying almost unconditional support especially in the past four decades. What has been said so far is nothing new in Washington's approach with regards to conflicts involving Israel. In this latest conflict however there were new elements in Washington's foreign policy. In previous conflicts which all took place in the Cold War era, the US was very careful in containing Israeli military operations to a limit that would not expand beyond its regional status. In the Cold War system each superpower was very careful in limiting the conflicts it was involved with in order to prevent an all out war using nuclear weapons. This characterized a Cold War arrangement in which all conflicts and potential wars were confined to certain rules and limits. This is why prior to the break up of the Soviet Union, Washington while strongly supporting Israel, was always careful that the Israeli war machine would not get out of hand (Khalidi, 2008). This is inline with the assumptions of neoclassical realist theory in which structural constraints and incentives form the major contours of a state's foreign policy.

The 2006 War of Lebanon marked the first Arab-Israeli war in the post-Cold War era and was thus not bound by the relatively stable and fixed rules of the past bipolar world system. Instead the new unipolar world system allowed Washington much more flexibility in its struggle to ensure its interests in the Middle East. Another important factor in understanding Washington's policy in the 2006 war was the new turn in US foreign policy, which took place after the events of September $11^{\text {th }}$. In this new approach, sought mainly by the neoconservatives who were now in power, a return to the old foreign policy doctrine of John Quincy Adams, which regarded Preemption, Unilateralism and Hegemony as its three main pillars, was in the works. It was in the context of this new worldview that Washington policy makers chose to encourage Israel to start the war, work hard to prevent an 'early' cease fire and even sought an expansion of the crises beyond Lebanon. This new ideological orientation of American decision-makers acted as a 'intervening variable' that led to the miscalculation of power relations in the region, resulting in high costs for both Israel and the United States.

\section{Course of Events}

Reports indicate that in their May $23^{\text {rd }} 2006$ meeting, Bush and Olmert agreed to focus their efforts to neutralize Iran's nuclear ambitions and increase pressure on Hezbollah and Hamas, which would in turn put pressure on their backers, namely Iran and Syria. At the same meeting Bush iterated his strong support for the upcoming military confrontation, in effect giving the green light to Olmert who had started planning for the attack since January according to leaked statements (Urquhart, 2007). Three days later Mossad agents killed Nidal and Mahmoud Majzoub two members of the Islamic Jihad at the Lebanese city of Sidon, which started a tit for tat cycle of violence. In reaction to the Sidon assassination, Islamic militants fired rockets into Israel that in turn counter attacked and killed a Hezbollah member. The situation was also worsened in Gaza, which had been under siege for some time. On June $23^{\text {rd }}$ Israeli commandos went into Gaza and kidnapped the two sons of Ali Muamar, a prominent Hamas member. Hamas retaliated by killing two Israeli soldiers and capturing Corporal Gilad Shalit (Parry, 2006). Israel's response was an escalation of its siege on Gaza in which it killed over 170 civilians in the month of July compared to 36 civilians killed in the month of June (Chomsky N. , 2008).

In effect the kidnapping of two Israeli soldiers on July $12^{\text {th }}$ that was presented to the people of the world as the basis for the war was just an excuse for an Israeli-American offensive. Hezbollah's tragic mistake was that it was hoping to initiate a new wave of prisoner exchange and also was aiming to reduce the pressure on the hard hit Gaza Strip, unaware that it was provoking an enemy itching to launch a full scale war. In reality Hezbollah fell into a well-orchestrated trap. Nasrallah confessed that he had misjudged the Israeli response stating, "We just wanted to capture prisoners for exchange purpose. We never wanted to drag the region into war" (Hersh, A Strategic Shift, 2007, pp. 61-62)

Although nobody can deny that Israel had its own reasons for attacking Lebanon and had been planning it for some time, nevertheless the Israelis found that the US administration not only approved of the plan but had intended to direct a crushing blow to Hezbollah and its backers and regarded it as a prelude for an attack on Iran. A Pentagon official told the New Yorker that the Bush White House "has been agitating for some time to find a reason for a preemptive blow against Hezbollah." He added, "It was our intent to have Hezbollah diminished, and now we have someone else doing it" (August 21 $1^{\text {st }} 2006$, pp. 30), or to put it in the words of Shmuel Rosner, the senior analyst for the Israeli newspaper Ha'aretz, "the way has been found for Israel to recompense the administration for its supportive attitudes during the six years of the Bush administration" (20 July 2006).

The initial plan according to Hersh was a major bombing campaign in response to the next Hezbollah provocation during which the Sunni and Christian population of Lebanon would turn against Hezbollah due to severe damages to Lebanon's infrastructure. The plan was first approved by Cheney and was later presented to 
Rice and Rumsfeld. Apparently Rumsfeld believed that Hezbollah was too dug in for an air only campaign to work, and was more interested in a larger ground attack, nevertheless senior intelligence officials indicated that Rumsfeld was "delighted that Israel is our stalking horse." Hersh also quotes a former intelligence officer: "We told Israel, 'Look, if you guys have to go, we're behind you all the way. But we think it should be sooner rather than later-the longer you wait, the less time we have to evaluate and plan for Iran before Bush gets out of office" (Hersh, Watching Lebanon, 2006, pp. 31-32).

\section{Pressure for Continuation and Expansion of the Conflict}

As the conflict progressed without Hezbollah losing its ground and its ability to fire rockets into Israel, concerns started to raise over how long the campaign would take and as civilian casualties especially in Lebanon mounted a growing voice in the international community pressed for a cease fire among the two parties, with UN Secretary General Kofi Annan calling for an "immediate cessation of hostilities and a far greater and more credible effort by Israel to protect civilians and infrastructure" (UN, 20 July 2006). The government of Lebanon frequently pled to the United Nations Security Council to call for an immediate and unconditional ceasefire between Israel and Hezbollah. Dissatisfaction with the war also grew in Israel as the War progressed.

The United States to a large part unilaterally pushed for a continuation of the war, with Condoleezza Rice publicly saying that a ceasefire should be put off until "the conditions are conductive" and that "a cease fire would be a false promise if it simply returns us to the status quo" (Zunes, 2008, p. 109). This basically meant that the US would go ahead in shaping a new Middle East according to its interests regardless of what the international community thought and regardless of the cost in human lives and the immense suffering of the Lebanese population. Rice insisted that the cost of the war was the "Birth Pangs of the new Middle East" [ibid]. US ambassador to the UN John Bolton went further saying that there was no moral equivalence between Israeli civilians and Lebanese civilians killed in the conflict (Bolton, 2006).

Months later Bolton publicly confessed to the BBC that the US and UK, with the support of several Arab leaders, delayed the ceasefire process (BBC News, 2007). Even as the conflict moved into its fourth week, the United States blocked cease fire efforts in the Security Council by threatening to veto draft resolutions, with Rice declaring that "there has been time that's been well spent over the last couple of weeks" in reference to the constant delays in establishing a cease fire (Office of the White House Press Secretary, August 7, 2006). In fact the US was so much involved in the ongoing war with Lebanon that according to veteran Israeli journalist Uri Avnery "Condoleezza Rice was back and forth, dictating when to start, when to stop, what to do, what not to do. America is fully complicit" and according to Ze'ev Schiff, dean of Israel's military correspondents "Rice is the figure leading the strategy of changing the situation in Lebanon, not Prime Minister Ehud Olmert or Defense Minister Amir Peretz" (Zunes, 2008, p. 94).

Halfway through the conflict the Jerusalem Post revealed that the US was interested in a strike on Syria: "Defense officials told the Post last week that they were receiving indications from the US, that America would be interested in seeing Israel attack Syria" (Katzidf, 2006). In the early stages of the war, Elliot Abrams, the influential US Deputy National Security Advisor, met with very senior Israeli officials to elaborate on Washington's view for the expansion of the war to Syria (Lobe, 2006), but according to Israeli sources Washington's idea was considered to be "nuts" by some senior Israeli officials and Israel decided not to go along with the plan (Parry, 2006). Meyrav Wurmser, the neoconservative director of the Centre for Middle East Policy who is an Israeli with close ties to the Likud party living in the US and whose spouse is a top Middle East adviser to Dick Cheney, said after the war that there was a lot of anger in Washington over Israel's decision in not attacking Syria. According to Wurmser, they "fought the wrong war and lost... instead of a strategic war that would serve Israel's objectives, as well as the US objectives" (Lobe, 2006).

Such ideological viewpoints effectively led Washington to misinterpret the balance of power in the region and as a result overestimate Israel's power in defeating Hezbollah and creating a "new" Middle East. Only when the situation became hopeless for Israel to win the war did Washington correct its policy and conceded to cease-fire demands by the international community. By the second week of August, the New York Times quoting a senior US administration official with Bush at his Crawford ranch wrote, "It increasingly seemed that Israel would not be able to achieve a military victory, a reality that led the Americans to get behind a cease-fire." (Aug. 12 $2^{\text {th }} 2006$ )

\section{Washington's Objectives}

In the latest Lebanon conflict the US and Israel each sought their own objectives. Although clearly their objectives overlapped in some areas, it cannot be said that they were entirely the same. This article deals mainly with the US involvement in the war however it is worth noting Israeli objectives in a summarized manner. Israel's strategic goals in its very long history of conflict with Lebanon have been generally constant. While 
some elements of its goals and the parties it was fighting have changed over time, nevertheless the basis of its aims have not changed. Israel has long sought to crush resistance to Israeli dominance whether it was the PLO in 82 or Hezbollah thereafter. Israel saw this resistance as encouragement and support for resistance in the occupied Palestinian territories. These resistance movements have also been a major barrier in installing a pro-Israeli government in Lebanon. Establishing a pro Israeli Christian government in Lebanon has been an Israeli goal from the very first years of the creation of Israel and was actively sought in the wars of 78 and 82 (Chomsky N. , 2008).

Later on however Israel scraped the 'Christian' part deeming it unfeasible. Israeli leaders starting with Ben Gurion (Israel's first prime minister) have always seen Lebanon as the weakest link in the Arab world. According to their mentality 'winning' Lebanon would pressure other Arab nations to yield to Israeli power or to put in a more diplomatic manner 'make peace with Israel'. Analysts such as Naomi Chomsky also list other Israeli motives such as their land expansionist mentality hoping that they would claim the Litani River as the northern border of Israel [ibid].

Washington is fighting a different struggle however. While supporting Israeli objectives and seeing a powerful Israel as assistance to their own plans, their struggle is a struggle to maintain and expand their hegemony in the world. While global hegemony has always been on Washington's agenda, in the Bush administration, with Neoconservatives sitting behind Washington's influential desks, it got new impetus. In this new agenda, the goal was to be advanced with the confrontation and eventual defeat of the Iran-Syria-Hezbollah-Hamas axis. The so-called 'War on Terror' had started. However not only was Al-Qaeda, the main perpetrators of the attack on 9/11 and the main trigger for the new shift in Washington's strategy, not connected to this axis, in fact they were opposed to Shia power, which were seen as "deviators" from the main teachings of Islam, from the point of view of Al-Qaeda and Salafis in general. The attack on Iraq was the first step in implementing this new plan. Saddam's Iraq, which was devastated both militarily and economically during the first Gulf War and the long years of UN sanctions, was not a significant and immediate threat either to the US or to Israel. Neither was it connected to the Iran-Syria axis or the Al-Qaeda camp. Indeed most Middle Eastern analysts agree that Saddam's Iraq was fundamentally opposed to both. The war in Iraq however was to be Washington's first step in showing the players of the Middle East and the world more generally, the new rules of the game in which Washington was the big player in town with the power to preemptively attack any country it deemed to be a 'threat.' In this regard Iraq was the weak link, a good 'target' which would be won quickly, putting decisive pressure on the other players in the Middle East like Iran and Syria.

Gradually the Iraq campaign started to go sour. The consequences for Washington's ambitious plans were enormous. Not only did the Iraq war not achieve the desired goals, rather it had the opposite effect of what was intended. Iran, with its rival powers on its eastern and western borders gone (the Taliban in Afghanistan and the Ba'ath party in Iraq), was now in an alleviated position in the Middle East's power struggle. Washington's bungling of the war had also cost one of its most powerful weapons, the weapon of 'threat', for not only had the world's largest military been bugged down by militias and crude methods in Iraq, it had also brought about a large opposition in the American public in regards to military intervention. With American forces already stretched too thin in Iraq and Afghanistan, Tehran and Damascus and their offspring's were in no mood to yield to Washington's power. This was well understood in Israeli power circles. In a secretly recorded statement made by Yuval Diskin, the director of the highly regarded Israeli internal security apparatus better known as Shin Bet, the top security official stated that Israel was better off with Saddam in power even going as far as saying "I'm not sure we won't miss Saddam" (Halpern, 2007).

The Israel-Hezbollah war in 2006 was a new opportunity for Washington to restart its ambitious plans for the Middle East. In this new approach the US and Israel could deal with the 'weak' Hezbollah first and then move on to the bigger fish of Syria and Iran, after which Hamas would be in no position to continue with its rejectionist policy of Israeli 'Peace Plans.' Just a couple of days after the conflict erupted, Robin Wright, the foreign policy analyst with the Washington Post, wrote that "for the United States, the broader goal is to strangle the axis of Hezbollah, Hamas, Syria and Iran, which the Bush administration believes is pooling resources to change the strategic playing field in the Middle East" (Washington Post, July $16^{\text {th }} 2006$ ). It should come as no surprise that House resolution 921 in support of Israel's offensive in Lebanon mentioned Iran and Syria 20 times. The resolution also stresses that George W. Bush "has repeatedly affirmed that Syria and Iran must be held to account for their shared responsibility in the recent attacks" (The United States House of Representatives, July 20, 2006, p. Res.921).

It was in this prevailing atmosphere that the US encouraged Israel to attack Syria. Iran was too strong to be attacked at the time and was too far away from Israel. However Syria was both close and also more vulnerable. 
Eliminating Hezbollah and weakening Syria would put Washington in a much more favorable position to confront Iran and solve the Middle East question once and for all. The new Middle East would be one in which no one would dare challenge American hegemony. This would make the US the 'boss' of the world's energy supply and would ensure its place as the world's sole superpower in the $21^{\text {st }}$ century. It was under this context that Secretary of State Condoleezza Rice, when asked about the enormous destruction and number of civilian casualties inflicted on Lebanon, called them "the birth pangs of a New Middle East," which was a pretty accurate statement of Washington's view of the conflict. In reality the 2006 Lebanon war was a proxy war in the sense that it was mainly a power struggle between the players of the Middle East, namely the US and Iran.

Neoclassical realism asserts that when domestic intervening variables lead to the deviation of a country's behavior from what structural factors predict (ideal foreign policy) the system punishes the state, resulting in the realization of past misperceptions and a correction of policy. This is why Rose (1998) asserts that even if the foreign policy of states might not track objective material power trends over the short to medium term, over the "long run a state's foreign policy cannot transcend the limits and opportunities thrown up by the international environment" (151).

In line with the above predictions, Washington's misperceptions about the power relations in the Middle East led to significant consequences. Washington's main miscalculation in creating a new 'Middle East' was overestimating the efficacy of its military force and that of Israel. While military superiority does assist in achieving political goals, nevertheless it usually cannot be applied without other political, cultural and economical means to solve a problem. Military superiority was also a decisive factor in building the overconfidence of the neoconservatives sitting in Washington. This overconfidence proved to be highly destructive to their cause. In addition to misunderstanding the balance of power in the Middle East, it led to the underestimation of their opponents, simplistic views of complex and historic issues, disregard for regional cultures and religions and the inter-rivalry between them, overestimating the power and willingness of regional allies like Israel, Saudi Arabia and Jordan to assist Washington's plans, and finally disregard for world opinion in an era that has been dubbed the 'Era of Communications.' All of this led to the fall of the neoconservative plan for a 'New Middle East.'

\section{Conclusion}

Like the Iraq war, the 2006 Lebanon War was a disaster for Washington and Tel Aviv. With the encouragement and support of Washington, the Israeli war machine fought an inconclusive war with Hezbollah, in which for the first time in recent decades caused its status as the 'Invincible Army' in the Middle East to vanish. Not only was Hezbollah not diminished but was rather strengthened during the conflict both inside Lebanon and in the Arab world, with ordinary Arabs seeing Hezbollah as the sole resistance movement outside Palestine standing up to Israeli aggression. It came as no surprise that a 2006 public opinion poll conducted in 6 Arab countries by the Anwar Sadat Chair for Peace and Development University showed that Hezbollah leader Seyed Hassan Nassrollah was the most popular figure in the Middle East by a large margin (Telhami, 2007). Indeed with so many satellite TV channels broadcasting up to the minute news on the war, it was almost impossible for Washington's regional allies like Saudi Arabia and Jordan to cover up the atrocities committed by Israel. Finally the conflict strengthened Iran even further for "If the most dominant military force in the region-the Israel Defense Forces - can't pacify a country like Lebanon, with a population of four million, you should think carefully about taking that template to Iran, with strategic depth and a population of seventy million" (Seymour Hersh quoting Richard Armitage, Deputy Secretary of State in Bush's first term) (Hersh, Watching Lebanon, 2006 , p. 29). Washington did not achieve any of its main objectives in the 2006 war and with the Israeli-Palestinian conflict, which plays a strategic role in Middle Eastern politics, unresolved, the crisis has taken a turn for the worse, and unfortunately it seems that the Middle East will see more conflicts in the near future.

\section{References}

Avnery, U. (2007, March 10). Olmert's Truth. Gush Shalom.

BBC News. (2007, March 22). Bolton admits Lebanon truce block. BBC News.

Bolton, J. (2006, July 17). Lebanon civilian deaths morally not same as terror victims -- Bolton. AFP.

Chomsky, N. (1999). The Fateful Triangle: The United States, Israel and the Palestinians. London: Pluto Press.

Chomsky, N. (2008). The War on Lebanon: A Reader. Massachusetts: Olive Branch Press.

CTV News. (2006, July 18). Bush points finger at Syria, Hezbollah for crisis. CTV News. 
Defense Security Cooperation Agency. (2006, July 14). Transmittal No. 06-40.

Halpern, O. (2007, January 5). Israeli Experts Say Middle East Was Safer With Saddam in Iraq. Jewish Daily Forward.

Hersh, S. (2006, August 21). Watching Lebanon. New Yorker Magazine.

Hersh, S. (2007, March 5). A Strategic Shift. New Yorker Magazine.

Kalman, M. (2006, July 21). Israel set war plan more than a year ago. San Francisco Chronicle.

Katzidf, Y. (2006, July 30). IDF prepared for attack by Syria. Jerusalem Post.

Khalidi, R. (2008). Preface. In N. Hovsepian, \& R. Khalidi (Eds.), The War on Lebanon: A Reader. Massachusetts: Olive Branch Press.

Lobe, J. (2006, December 19). Neo-Cons Wanted Israel to Attack Syria. Inter Press Service.

Office of the White House Press Secretary. (2006, August 7). President Bush and Secretary of State Rice Discuss the Middle East Crisis. Prairie Chapel Ranch, Crawford, Texas.

Parry, R. (2006, August 9). A 'Pretext War' in Lebanon. Consortium news.

Reuters. (2006, July 24). Israel to get U.S. "bunker buster" bombs.

Reuters. (2006, July 22). US rushes precision-guided bombs to Israel: paper.

Rose, G. (1998). Neoclassical Realism and Theories of Foreign Policy. World Politics, 51, 144-172. http://dx.doi.org/10.1017/S0043887100007814

Rosecrance, R. (1981). International Theory Revisited. International Organization, 35(4), 691-713. http://dx.doi.org/10.1017/S0020818300034287

Telhami, S. (2007). 2006 Annual Arab Public Opinion Survey. the Anwar Sadat Chair for Peace and Development University.

The United States House of Representatives. (July 20, 2006). Resolution 921.

UN. (20 July 2006). Secretary-General's briefing to the Security Council on the situation in the Middle East. New York.

United Sates Senate. (2006, July 18). Senate Resolution 534.

Urquhart, C. (2007, March 9). Israel planned for Lebanon war months in advance, PM says. The Guardian.

Waltz, K. N. (1979). Theory of International Politics. Long Grove, IL: Waveland Press.

Zafiris, T., \& Sayed, H. (2008). The War on Lebanon. Massachusetts: Olive Branch Press.

Zunes, S. (2008). In The War on Lebanon (p. Chapter 7). Massachusetts: Olive Branch Press.

\section{Copyrights}

Copyright for this article is retained by the author(s), with first publication rights granted to the journal.

This is an open-access article distributed under the terms and conditions of the Creative Commons Attribution license (http://creativecommons.org/licenses/by/3.0/). 